\title{
What are Institutional Logics - and Where is the Perspective Taking Us?
}

$\underline{\text { Authors }}$

Christina Berg Johansen, Copenhagen Business School, cbjo.ioa@cbs.dk

Susanne Boch Waldorff, Copenhagen Business School, sbw.ioa@ebs.dk 


\title{
What are Institutional Logics - and where is the perspective taking us?
}

\begin{abstract}
This study presents new insights into the explanatory power of the institutional logics perspective. With outset in a discussion of seminal theory texts, we identify two fundamental topics that frame institutional logics: overarching institutional orders guided by institutional logics, as well as change and agency generated by friction between logics. We use these topics as basis for an analysis of selected empirical papers, with the aim of understanding how institutional logics contribute to institutional theory at large, and which social matters institutional logics can and cannot explore and explain.
\end{abstract}

Key words: Institutional logics, institutional orders, institutional change, agency, theory development. 


\section{Introduction}

In the last decade we have witnessed an almost explosive rise in the number of scholars using the concept of Institutional Logics in their research (Lounsbury and Boxenbaum 2013; Greenwood et al. 2011). Articles in international journals increasingly refer to institutional logics, and conference seminars and workshops on institutional logics and institutional pluralism are flourishing (e.g. AOM 2014, EGOS 2010-14, New Institutionalism Workshop).

Yet, despite this escalating and intensive use of the institutional logics perspective, there has been surprisingly little attention to how researchers apply the concept in analysis; what the unique properties of the "logics" construct are and how it contributes to institutional theory at large. Many articles have compellingly explored novel territory for institutional theory, such as hybrid organizations that are able to combine previously competing logics, and logics studies have been successful in incorporating agency into our insights to institutional developments. It is still not clear, though, what is the explanatory power of institutional logics which - as any institutional perspective, should have "social matter"; it should help us investigate and understand something about the values, norms and developments of our social world. To illuminate these issues, we therefore in this paper explore the theoretical fundamentals and analytical contributions of the institutional logics perspective, as they are conveyed in the perspective's own conceptual writings and empirical studies. We want to utilize this awareness to engage in a discussion about the logics approach's capacity to inform our understanding of organizations in society.

We first ground our analysis of the conceptual writings in the overarching developments of institutional theory and the later decades' move towards change and agency. We then approach seminal definitions from central scholars of the institutional logics perspective and discuss their potential implications for empirical studies. We tease out two fundamental topics 
that define institutional logics' contribution to institutional theory: The impact of logics on social structure, and the change and agency generated by friction between logics.

These two topics structure our analysis of a selection of empirical studies of institutional logics across a range of international journals and books including Academy of Management Journal, American Science Quarterly, Organization Studies, Organization Science, Human Relations, and Research in the Sociology of Organizations. We extracted themes from the articles and built a table of 10 categories, such as "definition of logics", relationships between logics" and "core observations". We developed and structured the categories in iterations between data, theory and preliminary analyses, finally resulting in the two topics as core to our call for new paths in institutional logics.

Our key findings show that institutional logics is remarkably well founded in understanding the relationships and frictions between different logics, but is less concerned with understanding how logics relate to other institutional "levels" such as institutional orders or just "institutions". These conclusions lead us raise a number of concerns regarding the focus of the institutional logics perspective and to soliciting a stronger pursuit of institutional impact and a re-connection with the search for social meaning, values and consequence in institutional logics.

\section{The development of Institutional Logics theory}

Research on institutional logics is part of a broader trend of complexity studies in institutional theory, what we might call a "third wave" of institutional theory. 


\section{Institutional theory}

A core quest for institutional theory has always been to understand organizational action as something bound by more than economic reasoning and rational strategic goals. In institutional theory, a variety of social norms and values constitute larger social institutions, which put the organization under constant pressure. The organization is part of society and since society is not a uniform reality, the organization becomes subject to society's diverging values and norms and must maneuver in an ever-emerging and arbitrary sociality.

Looking back, the first wave of "old” institutionalism, spearheaded by Philip Selznick (1949, 1957, 1969), distinguished "institution" from "organization" and placed the organization in larger institutional environments and value-sets (Selznick 1996, Greenwood et al. 2014). It resonated aspects of contingency theory in its exploration of organizational responses to different values and demands inside and outside the organization (Greenwood et al. 2014), though it was less functionalistic than some of the contingency perspectives.

As the second wave, "new" institutionalism, arrived in the late 1970's, it was with a strong focus on the socializing effects of institutions, countering what was deemed a "rationalistic" and overly action-oriented approach to organizations' ability to adapt to their institutional environments - though as time has shown, there was perhaps little foundational difference between the old and the new institutionalism (Hirsch \& Lounsbury 1997). New institutionalism worked its way from groundbreaking articles on the dominance of culture and legitimacy over organizational autonomy (Zucker 1977; Meyer \& Rowan 1977; DiMaggio \& Powell 1983) to field-oriented studies of the diffusion of institutional norms across organizations (Hoffman, 1999; Munir, 2005), and the mimetic activities of organizations in the face of increased institutionalization of processes, structures and even values (Haveman, 1993; Oliver, 1991). An underlying current in neo-institutional theory treated plurality and 
paradoxical demands on the organization and observed the organizational responses to this primarily defined as decoupling (Meyer \& Rowan, 1977; Oliver, 1991). This current, however, received relatively little attention in neo-institutionalism which was, after all, focused on institutional similarities rather than differences.

The second wave of institutional theory, ironically, became increasingly functionalistic and abstract and suffered from ignorance of empirically observable issues: that organizations as well as institutions actually changed, and that some kind of action had to be causing this kind of change (DiMaggio, 1988; Powell \& DiMaggio, 1991; Seo \& Creed, 2002).

Hence the third wave, which in some ways bridges old and the new institutionalism (Greenwood \& Hinings 1996; Hirsch \& Lounsbury 1997). This wave, which we may call “change \& complexity” institutionalism, has evolved since the 1990's with the agenda to understand how pluralism in institutional demands is handled in organizations, and how organizational individuals and groups are active agents in institutional change (Battilana, 2006; Dacin, Goodstein, \& Scott, 2002). One perspective, "institutional work” has concerned itself intensively with actors and their individual agency in the ongoing development of institutions (Hwang \& Colyvas, 2011; Kraatz, 2011; Lawrence \& Suddaby, 2006; Lawrence, Suddaby, \& Leca, 2009), and another perspective, "institutional entrepreneurship" has concerned itself with "the activities of actors who have an interest in particular institutional arrangements and who leverage resources to create new institutions or to transform existing ones” (Battilana, 2006; Garud, Hardy, \& Maguire, 2007; Hardy \& Maguire, 2008; Maguire, Hardy, \& Lawrence, 2004). This highly agentic approach to institutions is confronted by institutional logics, a third and currently dominant perspective (Greenwood, Raynard, Kodeih, Micelotta, \& Lounsbury, 2011). Institutional logics scholars strive to understand institutional logics (a) as more abstract social structures than institutions; at a "meta-level" of values, norms and symbols, which make the institutions what they are (Thornton, Ocasio, \& 
Lounsbury, 2012), and (b) as coexisting in practical organizational life even though they are contradictory, where the friction between logics creates agency and potentially change.. In the next section we describe the theoretical guidelines and core concepts provided by seminal scholars of the field.

\section{The "birth" of Institutional Logics}

The theoretical and historical delineation of institutional logics is grounded in Friedland \& Alford's (1991) pioneering attempt to reconcile "the utilitarian individual" and "the poweroriented organization", offering institutional theory new explanations for institutional dynamics and change. Rooted in political and sociological discussions of what makes societies, Friedland and Alford argued that the co-existence of "potentially contradictory" (Friedland \& Alford 1991:240) institutions forms the basis of on-going societal transformation. They asked how different institutional arenas were both culturally and politically shaped, and argued that behind what they asserted as "the most important institutional orders" of Western societies (capitalism, family, the bureaucratic state, democracy, and Christianity), are "central logics". What the difference was between an institutional order and an institution was not explicated, thus we will regard them as identical and in the following consider the "orders" to be institutions in their own right, albeit very large ones.

Friedland and Alford defined institutional logics as "a set of material practices and symbolic constructions [that] constitute organizing principles" for institutions or "supraorganizational patterns of human activity" (ibid.:248;243). Actors engage in and play with ritual behavior, and thereby concretize and/or alter the symbols of a given institution, and they do this through highly tangible material practices that are connected to their individual lives and needs. In Friedland and Alford's perspective, then, it is important to recognize the difference between 
the institutional logic and the institution(s) it may support. Logics are more subtly powerful than institutions, in that they guide institutions and social meaning and are, perhaps, less tangible than the institutions themselves. Behind the institution of market, for example, is a more abstract or second-order logic that prescribes commodification of human activity (Friedland \& Alford, 1991). A logic is "a set of material practices and symbolic constructions" guiding the institution, such as e.g. "participation" in the institution of democracy, or "commodification of human activity" in the institution of capitalism (Friedland \& Alford, 1991). Thus, there is not a logic called "capitalism"; instead there are logics comprised of underlying practices and symbols - that make capitalism possible.

Friedland \& Alford were interested in critically reviewing the effects of hegemonic institutions such as capitalism on social life, and in understanding how actors related to these institutions. The logics construct would help guide our attention to the social content of institutions: "Without content - that is, the distinctive categories, beliefs and motives created by a specific institutional logic - it will be impossible to explain what kind of social relations have what kind of effect on the behavior of organizations and individuals" (Friedland \& Alford, 1991). Friedland and Alford sketched out what seemed a one-to-one relationship between a logic and an institution, such that capitalism could only and always be identified by a "commodification" logic. However, they did not elaborate these relationships. They claimed that certain institutional orders were congenitally organized through certain logics, e.g. as described above, that "the institutional logic of capitalism is accumulation and the commodification of human activity" (Friedland \& Alford 1991:248). There were few empirical - or theoretical - references for these claims. This did not pose a problem for the general premise of the article, but did little to help subsequent researchers in understanding how an institutional logic can be analyzed and defined. 
From a current perspective, however, the central point of the book chapter was that institutions and their foundational logics co-exist in society, and thus often create contradictory social arrangements. It is in these contradictions that institutions make room for individual and organizational action, and conversely, these actions transform institutions (ibid.:256). Institutional logics are not a pre-given social structure, but are enacted and shaped in individual and organizational action, and the authors argue for a nestedness of analytical levels, in which the interdependencies of individuals, organizations and institutions are key to identifying and analyzing logics (Friedland \& Alford 1991:241f.). These interdependencies are contingent to different social situations. Social situations and activities carry "multiple meanings or motivations" (ibid.:255), and actors can draw on different institutional logics for their purposes as well as be driven by several logics. Logics are thus complex, co-existing and there is "no one-to-one relationship between an institution and the meanings carried by the practices associated with it" (ibid.:255).

The nature of Friedland \& Alford's contribution (a chapter in Powell \& DiMaggios (1991) seminal book on "the New Institutionalism") shaped their argument as a general proposal to institutional theory, grappling with foundational conceptualizations of agency and structure, and left it open to further research to elaborate the empirical expressions of logics.

\section{The emergence of a field and the outline of a frame}

Elaborations of what institutional logics comprised and how they could be used in organizational analysis emerged in the following years (e.g. Haveman \& Rao 1997), and gained pace with Thornton \& Ocasio's (1999) development of an analytical framework for how "institutional logics shape power in organizations" (Thornton \& Ocasio 1999:803). Thornton \& Ocasio's empirical descriptions of actors and logics over time anchored the 
practices of actors in changing social structure, and stimulated scholarly interest in institutional logics.

The article elaborated the definition of institutional logics to comprise "the socially constructed, historical pattern of material practices, assumptions, values, beliefs, and rules by which individuals produce and reproduce their material subsistence, organize time and space, and provide meaning to their social reality" (ibid.:804), a definition frequently cited by subsequent studies.

Another, and perhaps more theoretically significant, contribution of their article was a typology by which logics could be identified and analyzed comprehensively. With this, the authors responded to Friedland \& Alfords call to identify "categories, beliefs and motives created by a specific institutional logic". The typology defined two industry-level logics, "editorial" and "market", and elaborated these in an ideal type framework aiming to identify generic categories such as legitimacy, authority structures, mission and strategy pertaining to the two logics. The relation between the institutional logics and their corresponding institutions was not subject to investigation, since the aim of the article was to uncover how "the sources of power, its meaning and its consequences" in an industrial field were contingent on institutional logics rather than on rational managerial strategies.

The typology has been expanded across a range of institutions and their characteristics in the authors' further work (Thornton 2004; Thornton \& Ocasio 2008; Thornton, Ocasio \& Lounsbury 2012), and today constitutes the most comprehensive theoretical framework in institutional logics theory: the "inter-institutional system". This elaborate framework encompasses seven institutions ("institutional orders") of market, corporation, profession, state, family, religion and community, all theorized across nine categories (Thornton, Ocasio \& Lounsbury 2012:73). The categories are derived across a vast array of theoretical constructs 
in social sciences and are intended to "discipline[ ] the researcher to identify abstract categories that simplify and distil the properties of new practices and the outcomes to be expected" (Thornton, Ocasio \& Lounsbury 2012:59). The proposition from Thornton et al. is that empirical research should qualify, verify and/or modify the categories, and thus over time help institutional theory strengthen the codes of each institutional order in terms of its logics' composition and associated micro-level expressions.

Throughout the rest of this article, we will investigate a good selection of empirical studies. The major part of institutional logics research is highly empirical and presents a multitude of interesting case studies that show logics at work. We will focus particularly on two core questions in order to pursue our interest in the theoretical and empirical contribution of the institutional logics perspective:

(1) Given that logics are what guide high-level "institutional orders" such as market, family and state (Friedland \& Alford, 1991; Thornton et al., 2012), how do scholars relate institutional logics to institutional orders and vice versa? We ask this question to understand what empirical studies show us about the contents and creations of foundational social structure in everyday organizational activity, and to discuss how this renews or reiterates existing notions of organization in institutional theory.

(2) Since logics are fundamentally argued to exist in relation to each other, with the friction between them being the trigger for institutional change and agency; then which types of relations do empirical studies identify? We ask this question to investigate what empirical research can tell us about how inter-logics relations work, and how friction between logics impact larger institutional developments.

We use the two questions to build up knowledge about the contribution of institutional logics to institutional theory at large. Furthermore, we want to utilize this awareness to engage in a 
discussion about the logics approach's capacity to inform our understanding of organizations in society. We are particularly interested in which social matters institutional logics can and cannot explore and explain.

\section{Institutional orders: guided by institutional logics?}

The foundational work on institutional logics asserts logics as "organizing principles"; something that "guide" higher-level "institutional orders" (Friedland \& Alford, 1991). Their originally suggested institutional orders have been amended several times in the work of Thornton \& Ocasio (Thornton, 2002; Thornton, 2004; Thornton \& Ocasio, 2008; Thornton et al., 2012) and today comprise the seven orders of family, community, religion, state, market, profession, and corporation. Each of these demarcates "unique organizing principles, practices and symbols that influence individual and organizational behavior" (Thornton et al., 2012). Institutional logics function as "frames of reference" that relate to these principles, practices and symbols, helping actors make sense of their world and construct their actions and identities (ibid.). Hence, institutional logics are related to institutional orders. This relation provides an interesting opportunity to institutional theory at large, potentially explaining how the overarching institutional orders, in which organizations are embedded, are created, maintained or contested through logics. When we as scholars observe institutional orders as meta-institutions, we are able to identify and discuss the deeper and taken-forgranted social layers, which embed those manifold logics we use in everyday life. And in reverse, when we observe everyday, institutionalized logics, we may trace how these compose and guide the more foundational social regimes called institutional orders. However, most of the empirical studies of institutional logics fall short of exploring the orders-logics relation, choosing instead to work with either one or the other. Furthermore, the existing designation of 
institutional orders seems to reify incumbent and dominant understandings of organization and society, thereby constricting our insight in the changes of real organizational life.

\section{What do we know about "orders"?}

In empirical analyses, several scholars take outset in the defined institutional orders themselves and in a sense conflate them with logics, then explore their empirical expressions (Ansari, Wijen, \& Gray, 2013; Goodrick \& Reay, 2011; Schneiberg, 2013; Voronov, De Clercq, \& Hinings, 2013; Waldorff, Reay, \& Goodrick, 2013). An example is Schneiberg (2013) who explores advocacy and resistance in the case of nationwide copying of bank practices from North Dakota. The study identifies a 'state', 'community' and 'market' logic in the empirical case, and analyses the frictions and interactions between these deductively identified constructs. Schneiberg's study, like most studies, does not investigate how these high-level logics (which correspond to the theoretical definitions of institutional orders) interact with actors' everyday logics. These two levels are the same - thus we learn little about how "state", "community" and "market" are (re-)created in daily institutional life; how they each become dominant.

Whereas some authors use institutional orders as logics, others mix them with self-defined logics, for example mixing a "community" logic with a "finance" logic (Almandoz, 2012), "market" with "aesthetic" logic (Voronov et al., 2013) or "market" with "editorial" logic (Thornton \& Ocasio, 1999). Another pathway is to identify logics based in existing literature on the empirical field and then look for new empirical representations of these logics. For example, Reay and Hinings $(2005,2009)$ locate the logics 'Business-like health care' and 'Medical professionalism' prior to their analysis, in a health care study by Scott et al. (Scott, Ruef, Mendel, \& Caronna, 2000), thus building upon - and extending - prior analysis of logics in the health care field. 
This way of using and mixing institutional orders and logics does not compromise the arguments of the articles, but it confuses the larger picture of the difference between higherlevel institutional orders and the logics that actors use in their daily interpretations of the orders. Equally important, it waters down the unique proposition of the institutional logics perspective; that Institutional Logics is a unique and specific understand of the colloquial term "logic", and not just another word for norms, practices, values - or institutions, for that matter.

If we turn to the types of institutional orders that appear in studies, we find that studies predominantly analyze those orders most prevalently associated with organizations; i.e. "market", "corporations", "profession", "state”, and "community" - whereas the orders "family" and "religion" are noticeably under-researched. Since institutional logics studies are mainly located in Western-world contexts driven by market capitalism, these latter two orders seem to be of peripheral interests - though for exceptions, see e.g. Ansari, Wijen \& Gray’s global perspective (Ansari et al., 2013), Anita Bhappu's description of the "family logic" in Japanese management (Bhappu, 2000) - or Roger Friedland's more theoretical ponderings of the logics of religion (Friedland, 2002; Friedland, 2013). The preoccupation with mainstream, organizational-capitalist orders reinforces a classical and somewhat narrow understanding of organizations as tangible actors in a market economy. Institutional logics studies thus far have done little to analyze movements, networks, families, religions etc., and also seem biased to Western forms of organization that are of interest to general management approaches. This narrowing of scope is further underscored by the selection of orders offered in the "idealtype" frameworks by Thornton and colleagues (Thornton \& Ocasio, 1999; Thornton, 2004; Thornton et al., 2012): major social structures such as science, art, philanthropy or education have, for some reason, no place in the framework. This resonates throughout the existing institutional logics studies, where we see very few explorations of orders outside the classical 
managerial disciplines. There are exceptions, such as Dunn \& Jones' (2010) exploration of "science" and "care" logics, but the general picture is that such orders (or logics, depending on the authors) have little relevance for institutional studies. We call attention to this finding because it reveals a blindness to those vast areas of social structure that lie beyond management and organization theory, yet still underlie and impact daily norms, values and logics in organizations. Institutional logics studies thus seem to represent a certain organizational conservatism.

\section{What defines a "logic"?}

A large number of studies define logics empirically, exploring logics as a set of norms, culture and social codes that belong to a certain organizations form. By describing the emergence of the organizational form, authors identify their norms and denominate them as logics. A series of studies takes a historical and longitudinal view, for example Michael Lounsbury's renowned study on trustee and performance logics in the mutual fund industry (Lounsbury, 2007), which portrays the historical, cultural and regional developments that created the two different logics. These studies are based on diligently coded empirical data that qualify emerging themes, which are then assembled into a set of logics, enabling them to e.g. trace the development of a care and a science logics across time (Dunn \& Jones, 2010). In these studies, institutional logics are connected with changing institutional norms that have tangible social impact. The interaction between orders and logics is disregarded, and it is not clear why the core topics are "logics" and not, for example, "institutions", but the studies offer palpable explanations of institutional impacts on social change.

Other studies employ a more pragmatic approach to defining logics, basing it on specific organizational contexts such as microfinance (Battilana \& Dorado, 2010), haute cuisine (Rao, Monin, \& Durand, 2003) or health care (Reay \& Hinings, 2009). By delving deeply 
into qualitative (interview \& observations) data, studies unearth the tensions between a 'banking' and a 'development' logic in microfinance organizations (Battilana \& Dorado, 2010) or identify 'modernist', 'formalist' and 'managerialist' logics in the French industrial design industry (Durand, Szostak, Jourdan, \& Thornton, 2013) or highly specific logics such as 'bureaucracy', 'children's welfare', 'seeing the whole person', and 'funding logics' in public housing organizations (Binder, 2007). The many empirically identified logics produce an impressive portfolio of different logics that are "out there", but convey little coherence in what makes up $a$ logic. Empirically identified logics range from field-level norms (Dunn \& Jones, 2010; Lok, 2010; Lounsbury, 2007) to specific local practices (Binder, 2007; Brown, Ainsworth, \& Grant, 2012; McPherson \& Sauder, 2013) and do not position the logics in reference to other institutional constructs such as "institutions" or "institutional orders". In this sense, it becomes uncertain what the particular offer is of the perspective "institutional logics" to institutional theory at large - notwithstanding that the studies themselves are both theoretically rigorous and empirically captivating. The identification of these logics in organizational development is interesting to the cases themselves, and to our understanding of how organizations can manage complex targets and processes, but this comes at the expense of understanding larger societal consequence.

\section{The use of ideal-type frameworks}

There is an emerging trend to probe into what we would call the "vertical relationships" internal to institutional logics and their more detailed compositions. Studies of this kind model themselves on the analytical reasoning of a Weberian "ideal type" system, in which selected characteristics of cultural meanings are interpreted "into their logically pure

components" (Thornton et al., 2012). Some studies specifically build on the inter-institutional framework ((Thornton et al., 2012) and its predecessors, i.e. Thornton 2002, 2004, Thornton \& Ocasio 1999, 2008) and empirically observe and analyze selected institutional orders or 
logics across some of the framework's characteristics (e.g. Almandoz 2012; Durand \& Szostak 2013; Pache \& Santos 2013; McPherson \& Sauder 2013). For example, Almandoz (2012) uses the characteristics "sources of legitimacy" and "basis of mission" to identify the use of financial and community logics in the founding teams of local banks, and thereby carves out the details in the differences of these two logics. Other studies make their own frameworks. Goodrick and Reay (2011) analyze a ‘state', 'profession', ‘corporation' and 'market' order across nine characteristics of pharmaceutical work in the US; e.g. evaluation of performance standards, employment status, or control over knowledge. This type of framework encompasses both higher-level institutional orders and their everyday constructions, thereby providing insight in historical changes in institutionalized work practices. However, it resonates the conflated view of logics and orders - being more a study of practices and symbols (as seen in the nine characteristics) in institutional change at large (as seen in the four grand "logics"), than of the functions of logics in the making and breaking of institutional orders.

Another example of internal vertical relationships of logics is Tracey, Philips \& Jarvis' (2011) framing of the "bridging work" of institutional entrepreneurs who combine two logics ("forprofit retail" and "nonprofit homelessness") to create a new organizational form. From axial coding of data, the authors generate three entrepreneurial activities; opportunity recognition (micro level), design of organizational form (meso level), legitimation of organizational form (macro level) - and assign two practices to each of these three; problem framing, counterfactual thinking, building organizational template, theorizing organizational template, connecting with macro-level discourse, aligning with highly legitimate actors. The study's contribution to the institutional logics perspective is an abstraction of the practices that are involved in managing conflicting logics. 
Very few articles explicitly work with the relationship between institutional orders and corresponding logics; an exception is McPherson \& Sauder (2013), who analyze "criminal punishment" as a logic underpinning the state order, "efficiency" as a logic underpinning a corporation order, and so forth - thereby empirically evaluating the relationships between logics and their (historically and culturally contingent) institutions.

Common to all these studies is the intricate analysis of the "how" of logics. The findings revolve around how actors handle different logics across identified characteristics. This does strengthen the arguments for what logics are and how we can observe them, but it ignores the relation of logics as frameworks for higher-level institutional orders. We gain detailed insight into the minute negotiations going on in the bridging and hybridization of logics, but we know less about the consequences of this social activity on the underlying institutional orders that logics guide and are guided by.

To recapitulate, institutional orders and-logics have been researched broadly: the portfolio of institutional logics is seemingly broad and covers a multitude of core organizational issues. When scrutinized, however, we notice a somewhat narrow conception of organizations and institutions in the empirical work - with orders and/or logics representing a fairly mainstream view of organization as market, bureaucracy (state), corporation, profession and communities. Another important finding is that institutional orders and-logics are rarely analyzed as a distinct relation, risking an oversimplification of the socializing practices that take place within a given institutional order. Institutional Logics tends to be used as a generalized construct with which we as institutional scholars explain social structure at whatever level, and though some scholars meticulously use ideal-type frameworks to uncover the underlying characteristics of specified institutional logics, we still know rather little about the dynamics between foundational, paradigmatic orders and the logics that actors employ to interpret and guide these. 


\section{Institutional change and agency: relationships between logics}

Another major potential of institutional logics to institutional theory is argued to be the capacity to explain institutional change and agency. This is conditioned by the definition of institutional logics as different 'sets of symbolic meaning and practices' (Friedland \& Alford, 1991), which co-exist and create friction in actors' perceptions of social reality. Because individual actors cannot readily reconcile the different logics, they must creatively find solutions to this friction.

A large number of the empirical studies of institutional logics analyze types of relationships between institutional logics; most prevalently as competing, co-existing, hybrids, or as institutional "bricolage" of two or more logics.

\section{Competition and co-existence}

Since the early days of institutional logics research, empirical studies have investigated 'competing' logics as those that cannot be reconciled in actors' cognition or practices, and thus create competing frameworks in daily organizational life. Sometimes, one logic gains dominance over another (e.g. Haveman \& Rao 1997; Rao, Monin \& Durand 2003; Pouthier et al. 2013), and at other times, they provide actors with divergent references (Lounsbury, 2007; Lounsbury \& Crumley, 2007; Marquis \& Lounsbury, 2007; Reay \& Hinings, 2005). Logics’ relations in these studies are temporally embedded, i.e. studied across a longer timeframe, and researched at a field level, providing a "grand view" of logics and how they change and are challenged by existing social behavior over time. This evidently comes at the cost of researching the everyday micro-agency involved; instead scholars focus on key actors and events (Lounsbury, 2007; Reay \& Hinings, 2005). 
A key contribution of the "competition" studies to institutional theory has been to explicate how organizations find themselves in paradoxical situations where irreconcilable logics force them to act. This is a different type of agency that the mimetic and isomorphic submission to external pressures which was previously of great interest to institutional scholars (DiMaggio \& Powell, 1983). Some studies in this vein observe the potential of logics in creating innovation. The almost normative observation point here is that logics' friction give rise to innovation, thus organizations who want something else than the status quo should strive to incorporate unfamiliar logics. Studies e.g. argue that it is beneficial for entrepreneurs to embrace competing logics (Almandoz, 2012), that mainly fringe companies or broadcompetence companies are capable of doing so (Durand et al., 2013), and that novel logics are adopted by those organizations that aspire to new and better future identities (Kodeih \& Greenwood, 2014).

In recent years, scholars have begun to identify multiple 'co-existing' logics (Goodrick \& Reay 2011; Durand et al. 2013; Raynard, Lounsbury \& Greenwood 2013) in "uneasy truce" (Reay \& Hinings 2005; Van Gestel \& Hillebrand 2011) or in a 'constellation of logics' (Goodrick \& Reay 2011; Waldorff, Reay \& Goodrick 2013; Smets \& Jarzabkowski 2013). This means that the relationship between logics may be competitive as well as cooperative. While competing logics indicate that strengthening one logic will result in weakening another logic, cooperative logics imply that different logics can mutually influence practices and that strengthening one logic may even result in consolidation of another logic [Waldorff, Reay \& Goodrick 2013]. Studies of co-existing logics convey a more dynamic understanding of logics, in which actors can move between logics depending on the time and organizational issues at hand. Also, the analyses of organizations become more nuanced, since they capture how actors drawing on different logics work together in the same organization. 
Summing up, the theoretical contribution of studies on competing and co-existing logics is to explain how logics evolve between organizations and broader society, and how social interactions create institutional change over time. Here, we are close to studies of institutional entrepreneurship (Battilana et al., 2009; Garud et al., 2007; Hardy \& Maguire, 2008; Maguire et al., 2004). The studies confront the neo-institutional legacy, where organizations were at the mercy of external normative pressures, and instead they show how institutional logics “co-evolve" between organizations and institutions over time (Lounsbury, 2007). The studies' aim is to identify which factors are involved in this co-evolution and why some logics gain prominence over other (Lounsbury, 2007; Rao, Monin, \& Durand, 2003) or how actors create “cooperative relationships" between different logics (Goodrick \& Reay, 2011). Some studies focus specifically on political processes and investigate how actors employ logics to resist or change structural initiatives (Marquis \& Lounsbury, 2007; Reay \& Hinings, 2005), adding a strategic dimension to agency (Townley, 1997). However, we also observe that there is a strong tendency to focus on the interplay between selected logics and the various ways by which actors deal with the embryonic friction between logics. We learn of types of events and actions through which logics become dominant, and what it takes to make different logics support each other. These studies show shifts in the power of logics, but seem detached from the ontological and practical consequences of these shifts.

\section{Hybrids}

In a second strand of studies researchers use the term 'hybrid' logics to describe organizations that bridge two previously separated sectors or fields of work, e.g. the non-profit development sector and the finance sector (Battilana \& Dorado 2010). This also includes budding work on social entrepreneurship, in which social good and profit motives are combined in one organizational model (Dacin, Dacin, \& Tracey, 2011; Nicholls, 2010; Pache \& Santos, 2013; Tracey, Phillips, \& Jarvis, 2011; Vurro, Dacin, \& Perrini, 2010). In organizations based on 
hybrid logics, two different and seemingly contesting logics support each other to uphold the organization, such as the social welfare logic and the commercial logic in organizations that train and re-employ unemployed citizens in France (Pache \& Santos, 2013). The goals of hybrid organizations could not be achieved with only one of the two logics - for example, state driven welfare services have not had success with finding jobs for unemployed people; they need to be connected to a different mode of "real work" through more commercially oriented helping organizations that both understand the job market and recognize the social contingencies of the unemployed. Studies of hybrid logics typically take place at the level of the organization, and we see several comparative studies in this vein. Scholars go "inside" the organizations and build case studies, using both observations and interviews. The studies identify strategic practices, such as deliberate hiring practices to bring in employees from particular work spheres fostering particular logics (Battilana \& Dorado, 2010); cognitive problem framing and "counterfactual thinking” to engage with other logics (Tracey et al., 2011); or structural, such as the decision to use specific standardization procedures or governance models depending on the logics invoked (Pache \& Santos, 2013).

The theoretical contribution of the hybrid relation studies is to present tangible expressions of the creative agency that arises in the friction between logics that have traditionally appeared irreconcilable. Hybrid studies point us to the institutional developments that create new organizational forms, such as microfinance (Battilana \& Dorado, 2010), social welfare and jobmarket (Pache \& Santos, 2013) community banking (Schneiberg, 2013) or social entrepreneurship (Tracey, Phillips, \& Jarvis, 2011). Ultimately, this offers a notion of how even the most calloused institutionalized praxis can change over time, through the creative reconceptualization of traditionally “competing” logics. However, we know little about how the logics become mixed - do actors for example use some characteristics of one logic and some of others and then recombine? Hybrid logics are generally described when they have 
already come into being. But we do not know how they are created - how creativity arises and changes the irreconcilable into the possible and valued.

\section{Bricolage}

Finally, a third category of research works with what we would call 'institutional bricolage': where multiple logics provide different materials for actors to choose and combine among (Ansari, Wijen, \& Gray, 2013; Binder, 2007; Christensen \& Lounsbury, 2013), or where actors consciously choose to pick certain elements from a given logic while leaving out other (Lok, 2010; McPherson \& Sauder, 2013; Voronov, De Clercq, \& Hinings, 2013). This implies a high degree of agency, since actors mold, resist, select and transform the available logics in their micro practices, and do not accept logics wholesale. Most institutional bricolage studies focus on micro-organizational developments and activity with and across individual actors.

The relations between the logics here become increasingly fragmented, since each logic contains myriads of characteristics that are either used or discarded by individuals in action. Some scholars present frameworks in the taxonomic tradition that Thornton et al. also base their ideal-type system on (Thornton et al., 2012): a series of sub-characteristics that can be analyzed across each logic. For example, Pache and Santos (2013) describe two logics with four underlying themes (goal, organizational form, control, professional legitimacy) and ten "organizational elements" in which logics prescribe "conflicting demands" (Pache \& Santos, 2013). We also observe research in which characteristics of different logics almost work as a “tool box" for actors in advocating their wishes and views (McPherson \& Sauder, 2013).

The novelty of the bricolage studies is to reveal and theorize the micro-activity negotiations that take place in and between logics and actors, and help us understand the intricacies of logics as they play out in everyday organizational life. The cost of such micro-foci, however, seems to be a decreased relevance for discussions of societal, institutional change. This is a 
well-known challenge for every micro-level study; it cannot easily embrace the scope of activity from individual reflection and action to societal transformation. Furthermore, we notice that in the logics bricolage studies, the actors are portrayed as individuals, who can choose among possible elements of different logics in their sensemaking of daily life. Yet we question this actor intentionality and the embedded understanding of rationality. We would like to know much more about the power struggles, ambiguity, change of mind or value contestations in these developments.

Summing up, our findings resonate with the account that the institutional logics perspective contribute to institutional theory by its capacity to explore and explain institutional change and agency. Moving away from understanding change as organizations' isomorphic adaption to external pressures, we see how the logics studies theorize institutional change by capturing the dynamic interactions between more logics and the venues for agency. This covers the whole range of perspectives; from the early studies of logics as competing and co-exiting, to the later studies of logics as hybrids or bricolage.

However, we also observe that there is a strong tendency to focus on the interplay between selected logics and the various ways actors deal with the friction between these logics. It is, in a sense, not the logic itself that is interesting, but the logic in interplay with other logics and the processes and venues for agency that this friction opens to actors. We find this is critical, because the process orientation comes at the expense of an in-depth knowledge of the studied phenomena and the logics' societal impact. It sometimes seems as if the empirical case is included in studies only to illustrate a given theoretical point.

Another challenge is the logics studies' growing attention to micro-level activity. Although this focus helps us understand the complexities in everyday organizational life, we know less about the broader societal, institutional change. In the logics studies, however, it is not just the 
micro-focus that takes away societal scope. The micro-level focus is often embedded in an almost functionalist understanding of agency, in which the actors are portrayed as rational individuals, who can choose strategically among (possible elements of) different logics in their sense making of daily life. We thereby understand at a high level of abstraction how actors relate logics to each other, but learn less of what the (constellations of) logics do to the actors and their organizations and surroundings.

\section{Discussion}

In this paper we pursued our interest in the theoretical and empirical contribution of the institutional logics perspective to institutional theory at large. We investigated how scholars relate institutional logics to institutional orders and their study of change and agency as generated by friction between logics. These two themes emerged in our review of the 'birth' of the institutional logics perspective as novel contributions to institutional theory and we went on to analyze the way these themes are dealt with in empirical studies. In this section we want to build upon our analysis and engage in a discussion about the contribution of the logics approach to institutional theory at large and, importantly, to our understanding of social reality. We are particularly interested in what researcher use the logics concept to explain; and what is not scrutinized by researchers.

Institutional logics "guide" institutions or "institutional orders". These orders have thus far been designated by central scholars of the perspective as the market, the corporation, professions, the state, community, family and religion. Yet, our first analysis showed that the interconnection of logics and orders is only rarely examined in the empirical analyses. Instead, logics and orders are often conflated, or logics are defined without attention to corresponding orders. Another band of studies uses empirical data for an inductive definition of the logics, though still not distinguishing them from institutional orders or other kinds of 
social structure. Finally, a small number of studies experiment with making logics explain institutional orders and strive to understand their composition in terms of ideal-type frameworks.

In our opinion, institutional logics should give insight in the "frames", or everyday social constructing, that is at work behind society's powerful institutional orders, therefore the relations between these different levels of institutional meaning are important to scrutinize. By e.g. studying which logics (social constructing) are involved in the dominance of the institutional order of "market", we could comprehend better why this order is so powerful in modern organizations, be they public, private or civil society. The choice to conflate these two constructs, or choose only one of them for study, circumvents the correspondence that exists between levels of institutional meaning. This, however, is perhaps easier given than taken, since theoretical counsel in identifying institutional logics vs. institutional orders leaves ample room for interpretation.

Our point is here that when institutional logics are not analytically constructed as a distinct form of "socially constructed [...] practices, values, beliefs and rules" (Thornton \& Ocasio, 1999); a form which clearly relates to the larger-scale institutions which institutional theory is essentially about, they are interchangeable with other concepts of agency-structure discussions, as they take place throughout sociology and organization theory. Using institutional logics to explain that there are conflicting norms and values in organizational development is - with the greatest respect for the many thorough studies in the field - neither a novel nor sustainable theoretical pursuit.

In our second analysis we saw that researchers have developed a broad range of analytical approaches to explore the relationships between logics and social reality in general. Moving from a focus on two competing logics, the studies investigate increasingly the co-existence of 
multiple logics. And from exploring mainly the processes from dominance of one macro-level logic to another, the studies now include how actors at more analytical levels consider and respond to institutional complexity. This development addresses the concern that focusing predominantly on duality/dialectics of logics over plural logics provides institutional theory with an over-simplification of real-life institutional change (see also Greenwood et al., 2011 for a critique of the dominant "dualism"). All together, the logics studies pay more attention to social reality as highly institutionalized and complex and should be analyzed as such. We support this development because we think it opens up for more interesting in-depth analysis of social reality with greater theoretical potential to explain the social complexity and dynamics. However, there is still a notable level of abstraction in the analysis of social reality.

One part of this abstraction relates to the strong commitment to work with logics in the "friction-sphere" with other logics. The logic is only interesting in its interplay with other logics and the processes and venues for agency that this interplay opens to actors. Recent critique of institutional logics has pointed out that current institutional theory is obsessing with explanations of process rather than phenomena (Greenwood, Hinings, \& Whetten, 2014). We second this critique, because we observe that the institutional logics studies seem to pursue the process route and therein refine the theoretical models and language of institutional discourse. Our main bone of contention is that the social consequences then appear peripheral in these process analyses. What we miss is the advancing of our insights into the societal impact of logics. Institutional logics work from points of observation where issues of value, ethics and problems of power, for example, are not discussed (Hirsch \& Lounsbury, 2014; Munir, 2014). Theorization is sophisticated, but the contribution to an understanding of what certain logics do to our world and organizations, is paid no heed. It would be interesting, for instance, to compare and discuss a number of analyses of the same logic. In which domains is the logic prevalent, what are the similarities and differences in the logic's manifestation in the 
values and practices in different cases, and what are the overall institutional developments and consequences of the logic for social reality? We would also like to know if the existence of a certain logic improves societal values and practices, and how we can evaluate this? And, finally, how the logics perspective can predict and inform us about future developments and challenges? If logics studies succeed in moving into this direction, we might achieve more explanatory than descriptive contributions. We call for stronger normativity in logics studies; a daring valuation of how developments matter to the aims, values and practices of the people they involve would be refreshing.

Another concern is that the institutional logics studies are organization-centric, meaning that research focuses mainly on conventional organizational phenomena such as managerial decision-making, innovation, professional identities and performance. The studies promote an implicit understanding of organizations as mainly traditional hierarchies. This is in line with Meyer and Höllerer (2004) who warns us that if institutional theory focuses only on formal organizations, the research will not capture the rapid fluctuations in contemporary forms of organizing such as the web based 'open source' developments. We will furthermore add that the analyses in our study reveal a very rational understanding of organizations and organizational actors. The logics are often treated as instrumental tools in the hand of the managers who are to create organizational changes. Or, the mangers are to deal with the pressures from new logics in the organization's institutional context. We learn of a range of different organizational and managerial practices involved in maneuvering strategically in a world of plural logics. This makes social phenomena such as norms and values concrete and tied to everyday decisions and strategies and shows how logics inform and are shaped in the smallest processes of daily life. Yet, we would like to know much more about the informal organization, the chaos and the 'muddling-through' in decision-making processes, and the actors' tiring negotiations and power struggles. 
Thirdly, the institutional logics perspective seems to be a business-school nested community, or at least grounded in a narrow scholarly interest tied to organizations that in one way or other are associated with the market: Public sector organizations are investigated from the viewpoint of increased marketization of structures and services (Binder, 2007; Goodrick \& Reay, 2011; Pouthier, Steele, \& Ocasio, 2013; Reay \& Hinings, 2005; Reay \& Hinings, 2009; Van Gestel \& Hillebrand, 2011), private companies from entrepreneurs to incumbents are core phenomena (Almandoz, 2012; Durand et al., 2013; Lok, 2010; Lounsbury, 2007; Lounsbury \& Crumley, 2007; Marquis \& Lounsbury, 2007; Thornton, 2002; Thornton, 2004; Voronov et al., 2013), and NGO's or social entrepreneurs have gained increased attention due to their mix of market logics with other more "social" logics (Battilana \& Dorado, 2010; Pache \& Santos, 2013; Pache \& Santos, 2010; Schneiberg, 2013). Since institutional fields and their organizational actors have been the historical nucleus of institutional theory, this is not surprising - but institutional logics could potentially contribute to understanding a broader scope of social practices and meanings related to organizations.

Looking outside institutional theory, the institutional logics perspective corresponds to many different perspectives on agency and social structure, for example framing (Kaplan, 2008) and cultural studies (Hatch \& Zilber, 2012; Hinings, 2011). Some authors draw on theoretical insights from other sociological currents such as critical realism (Delbridge \& Edwards, 2013; Leca \& Naccache, 2006), and there is a growing interest in the similarities between French pragmatist theory's "orders of worth" and the institutional logics perspective (Boltanski \& Thévenot, 2006; Boxenbaum, 2014; Brandl, Daudigeos, Edwards, \& PernkopfKonhäusner, 2014; Cloutier \& Langley, 2013; Friedland, 2013; Greenwood \& Langley, 2014; Pernkopf-Konhäusner, 2014).This correspondence on one hand creates potentially fruitful dialogues with organizational scholars in other fields, but on the other hand threatens to dilute the distinctiveness of institutional logics. 
Finally, we would like to point out that theoretical discussions of the institutional logics perspective are found in articles by scholars active in the field (Greenwood et al., 2011; Greenwood, Diaz, Li, \& Lorente, 2009; Lounsbury \& Boxenbaum, 2013; Meyer \& Höllerer, 2014). We think that these discussions and critique are crucial for our advancing of the explanatory power of the institutional logics perspective. Yet, the discussions spend less effort on theoretical foundations. There is still limited theorizing of what makes a logic a logic, of what demarcates logics from other social structure constructs (culture or values, for example), or of how logics impact the development of larger institutions (or "institutional orders").

\section{Conclusion}

In this paper we presented new insights into the explanatory power of the institutional logics perspective. Building upon a review of the institutional logics development as well as analyses of selected empirical articles, we explored how the institutional logics perspective contributes to institutional theory at large, and which social matters institutional logics can and cannot explore and explain, including the logics approach's capacity to inform our understanding of organizations in society. More specifically, we explored how scholars relate institutional logics to institutional orders, and their study of change and agency as generated by friction between logics. Our key findings show that institutional logics studies theorize the

relationships and frictions between different logics, but are less concerned with understanding how logics relate to other institutional "levels" such as institutional orders. These conclusions lead us to raise a number of concerns, including the institutional logics studies' narrow conception of organizations and institutions, their oversimplification of the socializing practices that take place within a given institutional order, their process orientation, and their 
almost functionalist understanding of agency. Based on our findings we call for a stronger pursuit of institutional impact and a re-connection with the search for social meaning, values and consequence in institutional logics. 


\section{References}

Almandoz, J. (2012). Arriving at the starting line: The impact of community and financial logics on new banking ventures. Academy of Management Journal, 53(6), 1381.

Ansari, S., Wijen, F., \& Gray, B. (2013). Constructing a climate change logic: An institutional perspective on the "Tragedy of the commons". Organization Science, 24(4), 1014-1040.

Battilana, J. (2006). Agency and institutions: The enabling role of individuals' social position. Organization, 13(5), 653-676.

Battilana, J., \& Dorado, S. (2010). Building sustainable hybrid organizations: The case of commercial microfinance organizations. Academy of Management Journal, 53, 1419-1440.

Bhappu, A. D. (2000). The japanese family: An institutional logic for japanese corporate networks and japanese management. Academy of Management Review, 25(2), 409-415.

Binder, A. (2007). For love and money: Organizations' creative responses to multiple environmental logics. Theory and Society, 36(6), 547-571.

Brown, A., Ainsworth, S., \& Grant, D. (2012). The rhetoric of institutional change. Organization Studies, 33(3), 297-321.

Dacin, M. T., Goodstein, J., \& Scott, W. R. (2002). Institutional theory and institutional change: Introduction to the special research forum. Academy of Management Journal, 45(1), 45-56.

DiMaggio, P. J. (1988). Interest and agency in institutional theory. In L. G. Zucker (Ed.), (pp. 3-21) Ballinger.

Dunn, M. B., \& Jones, C. (2010). Institutional logics and institutional pluralism: The contestation of care and science logics in medical education, 1967-2005. Administrative Science Quarterly, 55(1), 114-149.

Durand, R., Szostak, B., Jourdan, J., \& Thornton, P. H. (2013). Institutional logics as strategic resources. Research in the Sociology of Organizations, 39, 165-201.

Friedland, R. (2002). Money, sex, and god: The erotic logic of religious nationalism. Sociological Theory, 20(3), 381-425.

Friedland, R. (2013). God, love, and other good reasons for practice: Thinking through institutional logics. Research in the Sociology of Organizations, 39, 25-50.

Friedland, R., \& Alford, R. (1991). Bringing society back in: Symbols, practices and institutional contradictions. In W. Powell, \& P. Dimaggio (Eds.), The new institutionalism in organizational analysis (pp. 232-263). Chicago: University Of Chicago Press.

Garud, R., Hardy, C., \& Maguire, S. (2007). Institutional entrepreneurship as embedded agency: An introduction to the special issue. Organization Studies, 28(07), 957-969. 
Goodrick, E., \& Reay, T. (2011). Constellations of institutional logics: Changes in the professional work of pharmacists. Work and Occupations, 38(3), 372-416.

Greenwood, R., Raynard, M., Kodeih, F., Micelotta, E. R., \& Lounsbury, M. (2011). Institutional complexity and organizational responses. The Academy of Management Annals, 5(1), 317-371.

Hardy, C., \& Maguire, S. (2008). Institutional entrepreneurship. In R. Greenwood, C. Oliver, K. Sahlin \& R. Suddaby (Eds.), (pp. 198-217). London: SAGE Publications.

Haveman, H. A. (1993). Follow the leader: Mimetic isomorphism and entry into new markets. Administrative Science Quarterly, , 593-627.

Hoffman, A. J. (1999). Institutional evolution and change: Environmentalism and the US chemical industry. Academy of Management Journal, 42(4), 351-371.

Hwang, H., \& Colyvas, J. A. (2011). Problematizing actors and institutions in institutional work. Journal of Management Inquiry, 20(1), 62-66.

Kraatz, M. S. (2011). Two cheers for institutional work. Journal of Management Inquiry, 20(1), 5961.

Lawrence, T. B., \& Suddaby, R. (2006). Institutions and institutional work. In S. R. Clegg, C. Hardy, T. B. Lawrence \& W. R. Nord (Eds.), (2nd ed., pp. 215-254). London: SAGE Publications.

Lawrence, T. B., Suddaby, R., \& Leca, B. (2009). Introduction: Theorizing and studying institutional work. In T. B. Lawrence, R. Suddaby \& B. Leca (Eds.), (pp. 1-28). New York: Cambridge University Press.

Lok, J. (2010). Institutional logics as identity projects. Academy of Management Journal, 53(6), 1305 1335 .

Lounsbury, M. (2007). A tale of two cities: Competing logics and practice variation in the professionalizing of mutual funds. Academy of Management Journal, 50(2), 289-307.

Maguire, S., Hardy, C., \& Lawrence, T. B. (2004). Institutional entrepreneurship in emerging fields: Hiv/aids treatment advocacy in canada. Academy of Management Journal, 47(5), 657-679.

McPherson, C. M., \& Sauder, M. (2013). Logics in action managing institutional complexity in a drug court. Administrative Science Quarterly, 58(2), 165-196.

Meyer, R., \& Höllerer, M. (2014). Does Institutional Theory Need Redirecting. Journal of Management Studies, vol. 51, no. 7, 1221-1233.

Meyer, J. W., \& Rowan, B. (1977). Institutionalized organizations: Formal structure as myth and ceremony. American Journal of Sociology, 83(2), 340-363.

Munir, K. A. (2005). The social construction of events: A study of institutional change in the photographic field. Organization Studies, 26(1), 93-112.

Oliver, C. (1991). Strategic responses to institutional processes. Academy of Management Review, 16(1), 145-179. 
Powell, W. W., \& DiMaggio, P. J. (1991). In Powell W. W., DiMaggio P. J. (Eds.), The new institutionalism in organizational analysis University of Chicago Press. doi:10.2307/258726

Rao, H., Monin, P., \& Durand, R. (2003). Institutional change in toque ville: Nouvelle cuisine as an identity movement in french Gastronomy1. American Journal of Sociology, 108(4), 795-843.

Reay, T., \& Hinings, C. R. (2009). Managing the rivalry of competing institutional logics. Organization Studies, 30(6), 629-652.

Schneiberg, M. (2013). Lost in transposition? (A cautionary tale): The bank of north dakota and prospects for reform in american banking. In M. Lounsbury, \& E. Boxenbaum (Eds.), Institutional logics in action, part A (pp. 277) Emerald Group Publishing Limited.

Scott, W. R., Ruef, M., Mendel, P., \& Caronna, C. A. (2000). Institutional change and organizations: Transformation of a healthcare field. Chicago: University of Chicago,

Seo, M., \& Creed, W. E. D. (2002). Institutional contradictions, praxis, and institutional change: A dialectical perspective. Academy of Management Review, 27(2), 222-247.

Thornton, P. H. (2002). The rise of the corporation in a craft industry: Conflict and conformity in institutional logics. Academy of Management Journal, 45(1), 81-101.

Thornton, P. H. (2004). Markets from culture: Institutional logics and organizational decisions in higher education publishing Stanford University Press.

Thornton, P. H., \& Ocasio, W. (1999). Institutional logics and the historical contingency of power in organizations: Executive succession in the higher education publishing industry, 1958-1990 1. American Journal of Sociology, 105(3), 801-843.

Thornton, P. H., \& Ocasio, W. (2008). Institutional logics. The Sage Handbook of Organizational Institutionalism, 840

Thornton, P. H., Ocasio, W., \& Lounsbury, M. (2012). The institutional logics perspective: A new approach to culture, structure, and process Oxford University Press.

Tracey, P., Phillips, N., \& Jarvis, O. (2011). Bridging institutional entrepreneurship and the creation of new organizational forms: A multilevel model. Organization Science, 22(1), 60-80.

doi:10.1287/orsc. 1090.0522

Voronov, M., De Clercq, D., \& Hinings, C. B. (2013). Institutional complexity and logic engagement: An investigation of ontario fine wine. Human Relations,

Waldorff, S. B., Reay, T., \& Goodrick, E. (2013). A tale of two countries: How different constellations of logics impact action. Research in the Sociology of Organizations, 39, 99-129. 